\title{
A sea hare l-amino acid oxidase to fight multiple antibiotic-resistant Staphylococcus Aureus
}

\begin{abstract}
Staphylococcus aureus is a pathogen notoriously known for its ability to resist antibiotics. Here, we reported the activity of the sea hare Aplysia dactylomela ink L-AAO protein, dactylomelin-P, against 100 clinical isolates of multiple antibiotic-resistance $S$. aureus with a prevalence of $30 \%$ methicillin-resistant (MRSA). Dactylomelin-P was able to inhibit the growth of all isolates with inhibition zones average size of $17.90 \pm 2.58 \mathrm{~mm}$. Among the eleven commercial antibiotics tested, only vancomycin, quinupristin/dalfopristin and linezolid exhibited similar efficiency. These findings highlight the potential of dactylomelin-P against $S$. aureus and MRSA as well as support further research with dactylomelin-P as an antibacterial drug candidate.
\end{abstract}

Keywords: antibacterial protein, sea hare, MRSA
Volume 4 Issue 6 - 2017

\author{
Tallita CL Tavares, ' Vanessa LR Nogueira, ${ }^{2}$ \\ Gardenia L Batista, ${ }^{3}$ Vania MM Melo ${ }^{3}$ \\ IInstituto de Ciencias do Mar, Brazil \\ ${ }^{2}$ Universidade da Integracao Internacional da Lusofonia Afro \\ Brasileira, Brazil \\ ${ }^{3}$ Universidade Federal do Ceara, Brazil
}

\begin{abstract}
Correspondence: Vania MM Melo Laboratorio de Ecologia Microbiana e Biotecnologia, Departamento de Biologia, Bloco 909, Centro de Ciencias, Campus do Pici, Universidade Federal do Ceara, Av. Humberto Monte, 2775, 60.440-554 Fortaleza, Ceara, Brazil ,Tel 55-85-3366-98I4,Email vmmelo@ufc.br
\end{abstract}

Received: February 20, 2017 | Published: May 04, 2017

\section{Introduction}

S. aureus is a serious public health problem associated with superficial wounds to life-threatening infections, with hospital outbreaks and resistant clones emerging frequently. ${ }^{1}$ Since the $1960 \mathrm{~s}$, oxacillin (methicillin)-resistant $S$. aureus (MRSA) has established itself as one of the most common causes of nosocomial infections, whose dissemination has been of alarming concern. ${ }^{2}$ Therefore, the interest in discovering novel antibacterial agents with alternative mechanisms of action or unexploited bacterial molecular targets. ${ }^{3}$ Since the discovery of penicillin, more than 23,000 natural products have been characterized. ${ }^{4}$ Most of them were small secondary metabolites, however bioactive proteins has emerged concomitantly with advances in new analytical techniques for the isolation and characterization of these biomolecules.

Dactylomelin-P is a $60 \mathrm{kDa}$ monomeric protein purified from the purple ink of the sea hare Aplysia dactylomela that exhibits a wide range antibacterial activity. ${ }^{5}$ Several sea harescan excrete a deep purple ink when threatened by a predator. Besides pigments of algal origin, the ink is a rich source of toxic peptides and bioactive proteins (Figure 1).

Dactylomelin-P possess a minimum inhibitory concentration (MIC) of $0.1 \mathrm{mg} \mathrm{mL}-1$ against $S$. aureus ATCC 25923, with a mechanism of action based on its L-amino acid oxidase (L-AAO) activity against L-lysine and L-arginine. ${ }^{16}$ This represents a remarkable and economic mechanism of action related with the release of hydrogen peroxide (H2O2) directly on the site of infection as well as other intermediate products generated non-enzymatically with additional bactericide action. ${ }^{17}$ Considering the activity of dactylomelin-P against $S$. aureus ATCC 25923 and the increasing MRSA prevalence worldwide, here we examined its activity against 100 clinical isolates of multiple antibiotic-resistant $S$. aureus with a prevalence of $30 \%$ methicillinresistant (MRSA).

\section{Materials and methods}

\section{Microorganisms and antibiotics}

The microorganisms were kindly provided by the microbiology labs from three public hospitals of Fortaleza City, Ceará State, Brazil:
Albert Sabin Hospital; General Hospital of Fortaleza, Walter Cantídio Universitary Hospital, as well as from a private clinical laboratory. These isolates were obtained from abscesses, blood and urine cultures, cerebrospinal and pleural fluid, secretions, catheter tips and mitral valve. Eleven commercial antibiotics were tested against the isolates: oxacillin (1 $\mathrm{mg} /$ disk), penicillin (10 UI/disk); clindamycin (2 mg/disk), erythromycin (15 mg/disk), linezolid (30 mg/disk), sulfamethoxazole-trimethoprim ( $25 \mathrm{mg} /$ disk), vancomycin $(30 \mathrm{mg} /$ disk), quinupristin/dalfopristin (15 mg/disk), rifampicin (5 mg/disk), norfloxacin (10 mg/disk) and chloramphenicol (30 mg/disk).

\section{Antibiotic susceptibility test}

Dactylomelin-P was prepared at a concentration of $100 \mathrm{mg}$ $\mathrm{mL}^{-1}$ in $0.15 \mathrm{~mol} \mathrm{~L}^{-1}$ sterile saline. The susceptibility to antibiotics/ dactylomelin-P was tested by the disk diffusion method on MuellerHinton agar as standardized by the Clinical and Laboratory Standards Institute (CLSI). ${ }^{18}$

\section{Results and discussion}

Concerning the source of the isolates, the majority was from blood cultures and secretions (Figure 2). Obtaining $42 \%$ of the isolates in blood samples is alarming because $S$. aureus bacteremia is associated with high case fatality $(20-30 \%) .{ }^{19}$ All the isolates were penicillinresistant and sensible to vancomycin, quinupristin/dalfopristin and linezolid (Table 1). The prevalence of MRSA, oxacillin/methicillin resistant, was of $30 \%$ and most of the isolates were resistant to multiple antibiotics, which mean they were able to counteract different mechanisms of action (from cell wall synthesis to DNA topoisomerase inhibition). Four of them were resistant to at least seven antibiotics (oxacillin, penicillin, clindamycin, erythromycin, sulfamethoxazole/trimethoprim, rifampicin and norfloxacin). Resistance to erythromycin, sulfamethoxazole-trimethoprim and clindamycin reached $58 \%, 43 \%$ and $28 \%$, respectively. Particularly among the MRSA, the prevalence of resistant to those antibiotics was very elevate $(87 \%, 83 \%$ and $60 \%$, respectively) in comparison to the rates reported in previous studies..$^{20-22}$ Nowadays, it is common to see such resistance profiles, especially against clindamycin, due to haphazard use of these antibiotics. ${ }^{22}$ 


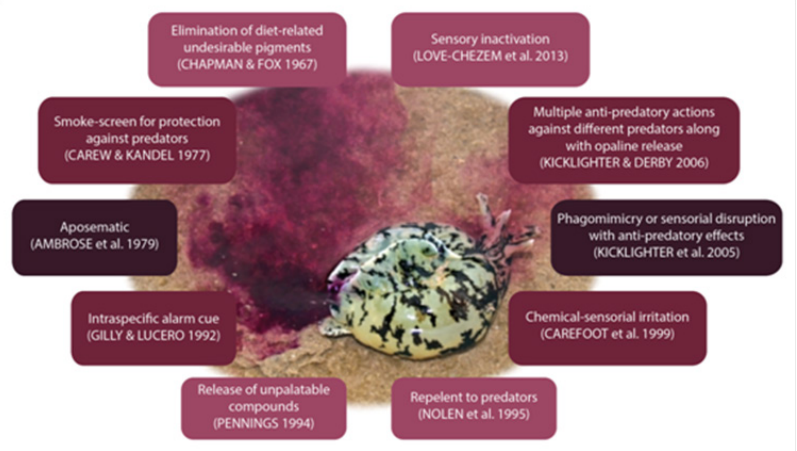

Figure I Chemical defense arsenal of the purple ink released by several sea hares. $^{6-15}$

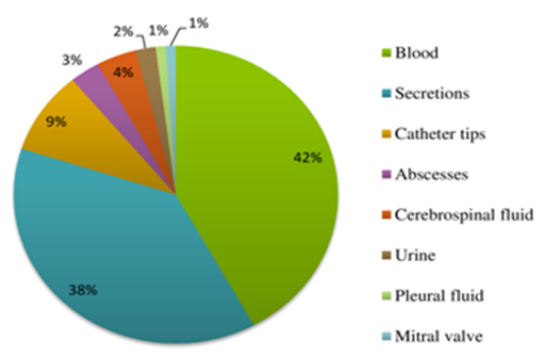

Figure 2 Sources of the clinical isolates of S. aureus tested in this current study.
A

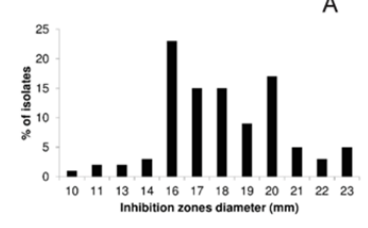

B

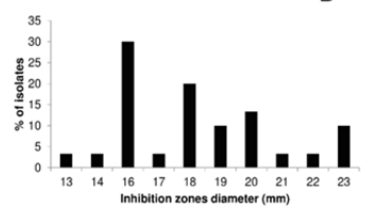

Figure 3 Inhibition zones diameters produced by dactylomelin-P against $\mathrm{S}$. aureus clinical isolates (A) and MRSA strains (B).

aNd-not determined

The prevalence of MRSA was $30 \%$, what is alarming in a hospital environment considering that resistance can spread fast. Other studies have also reported high prevalence of MRSA in clinical samples. ${ }^{20-22}$ Nowadays, vancomycin is used as drug of choice for treating MRSA, but the emergence of vancomycin intermediate-sensitive $S$. aureus (VISA) and vancomycin-resistant $S$. aureus (VRSA) has limited even this therapeutic route. ${ }^{2}$ In these more severe cases, the drugs of choice are quinupristin/dalfopristin, minocycline, daptomycin and linezolid. ${ }^{23-28}$ Taken together, these issues highlight the importance of searching new drugs to fight such pathogens.

\section{Conclusion}

In our study high rates of antibiotic resistance of clinical isolates of $S$. aureus were observed. Furthermore, our findings highlight the significant antibacterial activity of dactylomelin-P against those isolates including MRSA. Dactylomelin-P, with its alternative L-AAO-based mechanism of action, stood out with a different drugtarget interaction, which is very important currently for an effective action against multiple antibiotic-resistant $S$. aureus. Further studies are necessary to assess the effectiveness of dactylomelin-P for in vivo applications.

Table I Percentage of S. aureus strains resistant to commercial antibiotics among 100 clinical isolates

\begin{tabular}{|c|c|c|c|c|c|c|c|c|c|c|c|c|c|}
\hline \multirow{2}{*}{ Source } & \multirow{2}{*}{$\begin{array}{l}\text { Number of } \\
\text { strains }\end{array}$} & \multicolumn{12}{|c|}{ Resistant strains (\%) } \\
\hline & & OXA & PEN & CLI & ERY & LZD & SXT & VAN & QD & RIF & NOR & CHL & DACT \\
\hline Wound & 38 & 19 & 100 & 37 & 50 & 0 & 35 & 0 & 0 & 5 & 50 & 50 & 0 \\
\hline Catheter & 9 & 55 & 100 & 80 & 33 & 0 & 55 & 0 & 0 & 22 & 50 & 50 & 0 \\
\hline Hemoculture & 42 & 38 & 100 & 26 & 65 & 0 & 58 & 0 & 0 & 7 & 30 & 70 & 0 \\
\hline Urine culture & 2 & 0 & 100 & 0 & 0 & 0 & 50 & 0 & 0 & $\mathrm{Nda}$ & $\mathrm{Nd}$ & $\mathrm{Nd}$ & 0 \\
\hline Abscess & 3 & 0 & 100 & 0 & 67 & 0 & 35 & 0 & 0 & $\mathrm{Nd}$ & 33 & 65 & 0 \\
\hline Liquor & 5 & 20 & 100 & 0 & 40 & 0 & 60 & 0 & 0 & 35 & 20 & 0 & 0 \\
\hline Mitral valve & 1 & 100 & 100 & 0 & 100 & 0 & 100 & 0 & 0 & $\mathrm{Nd}$ & 0 & 0 & 0 \\
\hline Total of strains & 100 & 30 & 100 & 28 & 58 & 0 & 43 & 0 & 0 & II & 18 & II & 0 \\
\hline
\end{tabular}

OXA: Oxacillin; PEN: Penicillin; CLI: Clindamycin; ERY: Erythromycin; LZD: Linezolid; SXT: Sulfamethoxazole-trimethoprim;VAN:Vancomycin; QD: Quinupristin/ dalfopristin; RIF: Rifampicin; NOR: Norfloxacin; CHL: Chloramphenicol; DACT: Dactylomelin-P

\section{Conflicts of interest}

There is no conflict of interest.

\section{Acknowledgements}

None.

\section{Funding}

None.

\section{References}

1. Atya AKA, Belguesmia Y, Chataigne G, et al. Anti-MRSA Activities of Enterocins DD28 and DD93 and Evidences on Their Role in The Inhibition of Biofilm Formation. Front Microbiol. 2016;7:1-12.

2. Kshetry AO, Pant ND, Bhandari R, et al. Minimum inhibitory concentration of vancomycin to methicillin resistant Staphylococcus aureus isolated from different clinical samples at a tertiary care hospital in Nepal. Antimicrob Resist Infect Control. 2016;5:27.

3. Kurosu M, Siricilla S, Mitachi K. Advances in MRSA drug discovery: where are we and where do we need to be? Expert Opin Drug Discov. 2013;8(9):1095-1116. 
4. Katz L, Baltz RH. Natural product discovery: past, present, and future. $J$ Ind Microbiol Biotechnol. 2016;43(2-3):155-176.

5. Melo VMM, Duarte ABG, Carvalho AFFU, et al. Purification of a novel antibiotic and haemagglutinating protein from purple fluid of the sea hare Aplysia dactylomela Rang 1828. Toxicon. 2000;38(10):1415-1427.

6. Chapman DJ, Fox DL. Bile pigment metabolism in the sea-hare Aplysia. Journal of Experimental Marine Biology and Ecology. 1967;4:71-78.

7. Carew TJ, Kandel ER. Inking in Aplysia californica. J Neurophysiol. 1977;40(3):692-707.

8. Ambrose HW, Givens RP, Chen R, et al. Distastefulness as a defense mechanism in Aplysia brasiliana (Mollusca:Gastropoda). Marine Behavior \& Physiology. 1979;(1):57-64.

9. Gilly WF, Lucero MT. Behavioral responses to chemical stimulation of the olfactory organ in the squid Loligoopalescens. The Journal of Experimental Biology. 1992;162:209-229.

10. Pennings SC. Interspecific variation in the chemical defenses in the sea hares (Opisthobranchia: Anaspidae). Journal of Experimental Marine Biology and Ecology. 1994;180:203-219.

11. Nolen TG, Johnson PM, Kicklighter CE, et al. Ink secretion by the marine snail Aplysia californica enhances its ability to escape from a natural predator. Journal of Comparative Physiology. 1995;176(2):239254.

12. Carefoot TH, Pennings SC, Danko JP. A test of novel function(s) for the ink of sea hares. Journal of Experimental Marine Biology and Ecology. 1999;234(2):185-197.

13. Kicklighter CE, Shabani S, Johnson PM, et al. Sea hares use novel antipredatory chemical defenses. Curr Biol. 2005;15(6):549-554.

14. Kicklighter CE, Derby CD. Multiple componentes in the ink of the sea hare Aplysia californica are aversive to the sea anemone Anthopleura sola. Journal of Experimental Marine Biology and Ecology. 2006;334(2):256-268

15. Love Chezem T, Aggio JF, Derby CD. Defense through sensory inactivation: sea hare ink reduces sensory and motor responses of spiny lobsters to food odors. J Exp Biol. 2013;216(pt 8):1364-1372.

16. Tavares TCL, Nogueira VLR, Vasconcelos IM, et al. Further characterization and mode of action of dactylomelin-P, an antibacterial protein isolated from the ink of the sea hare Aplysia dactylomela. $J$ Exp Mar Biol Ecol. 2011;407(2):200-206.

17. Ko KC, Tai PC, Derby CD. Mechanisms of Action of Escapin, Bactericidal Agent in the Ink Secretion of the Sea Hare Aplysia californica: Rapid and Long-Lasting DNA Condensation and Involvement of the OxyR-Regulated Oxidative Stress Pathway. Antimicrob Agents Chemother. 2012;56(4):1725-1734.
18. NCCLS, National Committee for Clinical Laboratory Standards. Performance Standards for Antimicrobial Disk Susceptibility Tests. Approved Standard-Eighty Edition. NCCLS document M2-A8. Pennsylvania, USA. 2003.

19. Caffrey AR, Timbrook TT, Noh E, et al. Evidence to support continuation of statin therapy in patients with Staphylococcus aureus bacteremia. Antimicrob Agents Chemother. 2017;61(3):e02228-16.

20. Shrestha B, Pokhrel BM, Mohapatra TM. Phenotypic characterization of nosocomial isolates of Staphylococcusaureus with reference to MRSA. J Infect Dev Ctries. 2009;(7):554-560.

21. Ansari S, Nepal HP, Gautam R, et al. Threat of drug resistant Staphylococcus aureus to health in Nepal. BMC Infect Dis. 2014; $14: 157$.

22. Belbase, A, Pant N D, Nepal K, et al. Antibiotic resistance and biofilm production among the strains of Staphylococcus aureus isolated from pus/wound swab samples in a tertiary care hospital in Nepal. Ann Clin Microbial Antimicrob. 2017;16(1):15.

23. Rivera AM, Boucher HW. Current Concepts in Antimicrobial Therapy Against Select Gram-Positive Organisms: Methicillin-Resistant Staphylococcus aureus, Penicillin-Resistant Pneumococci, and Vancomycin-Resistant Enterococci. Mayo Clin Proc. 2011;86(12):12301243 .

24. Kasai K, Ishikawa T, Nakamura T, et al. Antibacterial properties of L-amino acid oxidase: mechanisms of action and perspectives for therapeutic applications. Appl Microbiol Biotechnol. 2015;99(19):78477857.

25. Ehara T, Kitajima S, Kanzawa N, et al. Antimicrobial action of achacin is mediated by L-amino acid oxidase activity. FEBS Lett. 2002;531(3):509512.

26. Lee ML, Tana NH, Funga SY, et al. Antibacterial action of a heat-stable form of L-amino acid oxidase isolated from king cobra (Ophiophagus hannah) venom. Comp Biochem Physiol C Toxicol Pharmacol. 2011;153(2):237-242.

27. Kitani Y, Kikuchi N, Zhang G, et al. Antibacterial action of L-amino acid oxidase from the skin mucus of rockfish Sebastes schlegelii. Comp Biochem Physiol B: Biochem Mol Biol. 2008;149(2):394-400.

28. Kasai K, Ishikawa T, Komata T, et al. Novel L-amino acid oxidase with antibacterial activity against methicillin-resistant Staphylococcus aureus isolated from epidermal mucus of the flounder Platichthys stellatus. FEBS J. 2010;277(2):453-465. 